\title{
CONTROL OF HYDROSTATIC TRAVEL DRIVE SYSTEM IN EARTH MOVING MACHINES
}

\author{
Biały Jarosław, Krasuski Jan, Łopatka Marian \\ Przychodzień Tadeusz
}

Institute of Building Machines, Military University of Technology, Warsaw, POLAND

\section{ABSTRACT}

Aplication of hydrostatic travel drive system in tractor earth-moving machines enables a precise control of digging process according to given requirements and limits. A paper present some problems connected with this subject which have been chosen by the authors as the most important ones.

\section{INTRODUCTION}

Most of the tractor earth-movers such as bulldozers, loaders, scrapers etc. operate in cycling and make during a working cycle (which lasts from a few to a dozen or so seconds) a few relatively short distances. Such a cycling work requires almost continuous and adequately correlated control of direction and parameters of power applied to wheels or tracks and piston rods of hydraulic cylinder enabling the changes of attachement position in respect of chassis.

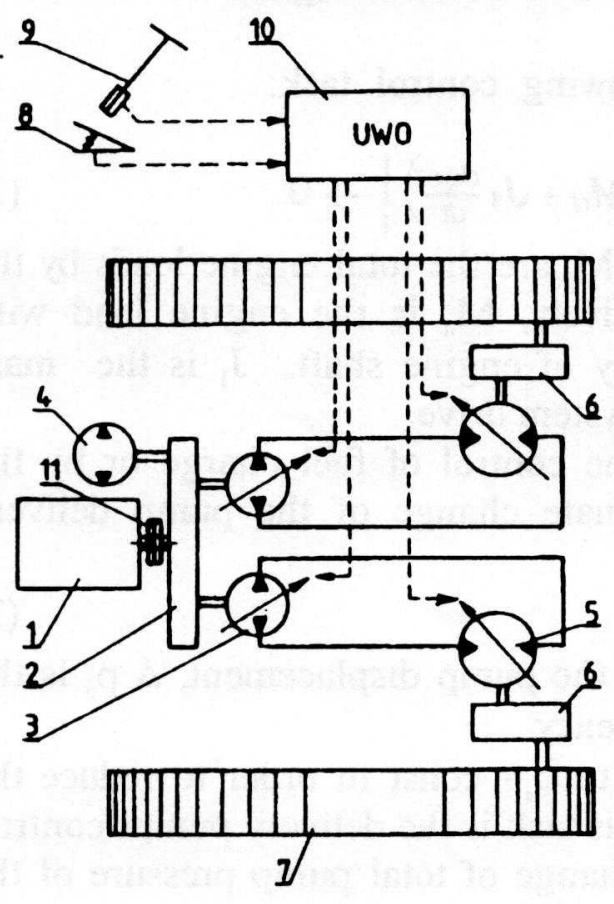

Nowadays used travel drives which contain a single or double-stage torque converters of non-controllable characteristic and a power shift transmission are difficult to control. Hydrostatic transmissions (Fig. 1) are much advantageous as regards the control possibility. They make it possible to automatically control machine operation according to various programs and using various techniques, especially micro-processor ones.

Fig.1. Scheme of hydrostatic transmission : 1 - diesel engine, 2 - gearbox, 3 - variable flow pump, 4 - added pump, 5 - variable displacement motor, 6 - final drive, 7 track, 8,9 - steering wheel and pedal, 10 micro-computer

The main purpose of automation is increase in machine efficiency which is understood as energy-consumption, hourly production, and accurancy of their working 
processes. The basic methods and conditions for such purpose attainment are discribed in our paper.

\section{OPTIMUM ENGINE LOADING}

The basic condition which makes it possible to reduce a fuel consumption is such engine loading, during the working process, is such that probability of engine operation with minimum specific fuel consumption would be the highest (Fig.2).

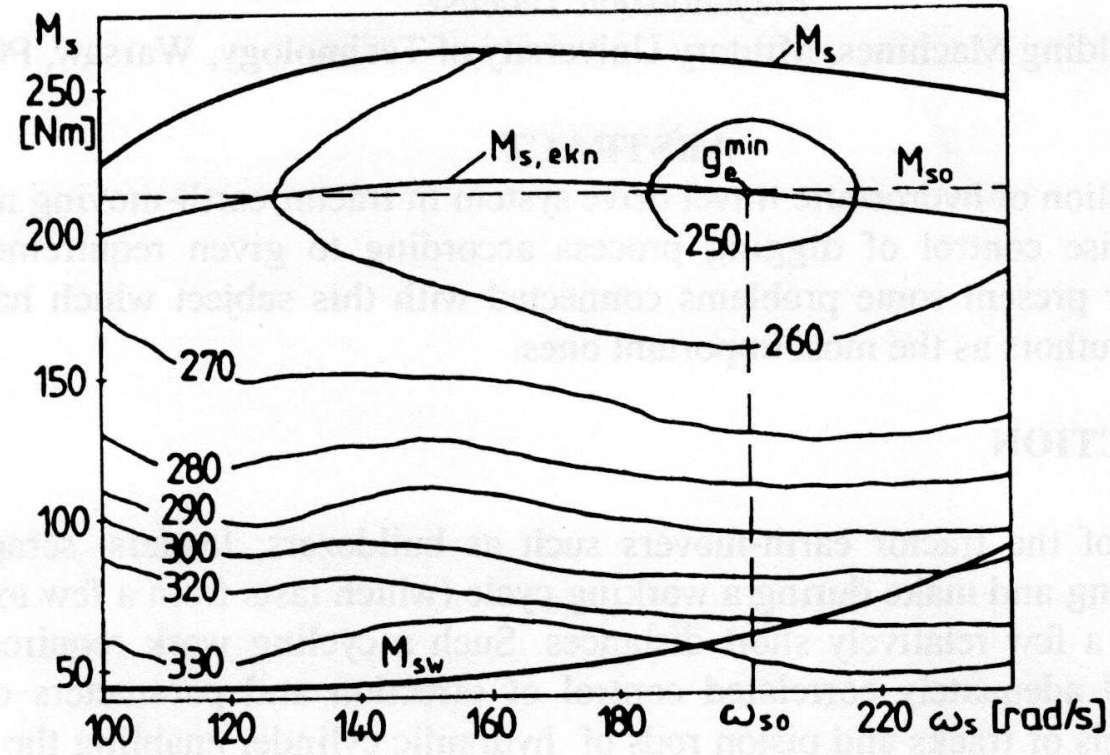

Fig.2. Fuel consumption characteristic of SW 680 engine

Such a condition can be taken as the following control task:

$$
\left|M_{s, e c o n}-\left(\Sigma M_{p j}+\Sigma M_{p o}+M_{d}+J_{1} \frac{d \omega s}{d t}\right)\right| \rightarrow 0
$$

where $M_{\text {o,econ }}$ is the optimum engine load, $\Sigma \mathrm{M}_{\mathrm{pj}}, \Sigma \mathrm{M}_{\mathrm{po}}$ are the total engine loads by the pumps of travel and attachment drives, respectively, $M_{d}$ is the engine load with additional mechanisms, $\omega_{c}$ is the angular velocity of engine shaft, $J_{1}$ is the mass moment of inertia of the mobile elements of the system drive.

The task (1) can be accomplished by the control of fuel charge or by the control of pumps loading as a result of adequate change of the pump delivery according to the dependence :

$$
M_{p}=\frac{1}{2 \pi} \cdot \frac{\varepsilon_{p} \cdot q_{p} \cdot \Delta p_{p}}{\eta_{m h p}}
$$

where $\varepsilon_{p}$ is the setting parameter of pump, $q_{p}$ is the pump displacement, $\Delta p_{p}$ is the pressure increase, $\eta_{\text {mpp }}$ is the pump mechanic efficiency'.

The fuel charge is controlled according to $\omega_{3}=$ const in order to reduce the inertion losses. The basic method to accomplish this task is the delivery pumps control. The flow controller can respond directly to the change of total pump pressure of the 
travel and attachement systems or can respond to the change of engine shaft speed, caused by such pressure changes. In practice the latter method can be insufficiently accurate as a direct method because the changes of the engine speed, operating according to the control characteristic, are relatively small even in case of significant load changes.

\section{EFFECTIVE FORMATION OF TRAVEL DRIVE LOAD}

The power balance of travel drive with the $j=1 \ldots n_{j}$ drive wheels or tracks with hydrostatic transmition (Fig.1) may be expresed as :

$$
\omega_{s} \sum_{j} M_{p j}=\sum_{j} \frac{1}{\eta_{u j}} T_{j} v_{j}
$$

where

$$
T_{j}=P_{n j}-f_{j} R_{j}=\left(\varphi_{j}-f_{j}\right) R_{j} \leq\left(\varphi_{j \max }-f_{j}\right) R_{j}
$$

where $P_{r j}$ is the gross traction, $T_{j}$ is the net traction, $R_{j}$ is the load on wheel or track, $\eta_{u j}$ is the efficiency of travel drive, $f_{j}$ is the rolling resistance factor, $\varphi_{j}$ is the traction factor, $v_{j}$ is the traction speed, where :

$$
v_{j}=v_{t_{j}} \cdot\left(1-\delta_{j}\right)=\frac{r_{j} \cdot \omega_{s} \cdot k_{j j}}{I_{m}} \cdot\left(1-\delta_{j}\right)
$$

where $v_{t j}$ is the theoretical traction speed, $r_{j}$ is the radius of drive wheel or sprocket, $i_{k}$ is the kinematic transmission ratio of hydrostatic drive, $i_{m}$ is the transmition ratio of mechanical drive part, $\delta$ is the wheel or track slip, $\eta_{u j}$ is the travel drive efficiency.

The travel drive efficiency can be described as :

$$
\eta_{u j}=i_{k j} i_{d j} \eta_{m} \eta_{z j}
$$

where $i_{d}$ is the dynamic transmission ratio of hydrostatic drive, $\eta_{m}$ is the efficiency of gearbox, $\eta_{j}$ is the efficiency of co-operation wheel or track with soil.

The efficiency of co-operation wheel or track with soil is:

$$
\eta_{z j}=\frac{T_{j j} \cdot v_{j}}{P_{n j} \cdot v_{\gamma_{j}}}=\frac{T_{j}}{P_{n j}}\left(1-\delta_{j}\right)=\frac{\left(\varphi_{j}-r_{j}\right) \cdot\left(1-\delta_{j}\right)}{\varphi_{j}}
$$

Considering inertion of drive system and neglecting its elasticity and damping, the driving force $P_{\mathrm{ri}}$ can be expressed as the following relationship :

$$
P_{n j}=\frac{M{ }_{p} j}{T_{j}} \cdot i_{d_{j}} \cdot i_{m} \cdot \eta_{m}-\frac{1}{r^{2}} \cdot \frac{d v_{i j}}{d t} \cdot\left[i_{m} \cdot\left(i_{d_{j}} \cdot J_{1} \cdot \frac{d \omega_{s}}{d \omega_{2}}+J_{2 j}\right)+J_{j}\right]
$$

where $\omega_{\mathrm{gj}}$ is the angular velocity of hydraulic motor, $\mathrm{J}_{\mathrm{j}}$ is the mass moment of inertia of mobile elements reduced on hydraulic motors shaft, $\mathrm{J}_{\mathrm{j}}$ is the mass moment of inertia of running gear reduced on sprocket axis.

It results from the analysis of the relationships (6), (7), and (8), assuming $\eta_{\mathrm{m}}=$ const, that the smallest losses of the transmitting drowbar-pull power in case when :

1) the engine operates with the fixed speed - the losses of power for acceleration of running gear and drive system are minimum;

2) the setting parameters of the pumps $\varepsilon_{\mathrm{pj}}$ and motor $\varepsilon_{\mathrm{ij}}$ of the hydrostatic transmission are controlled according to the hyperbolic characteristic of transmission ratios $i_{k j} i_{d j}=$ const; 
a)

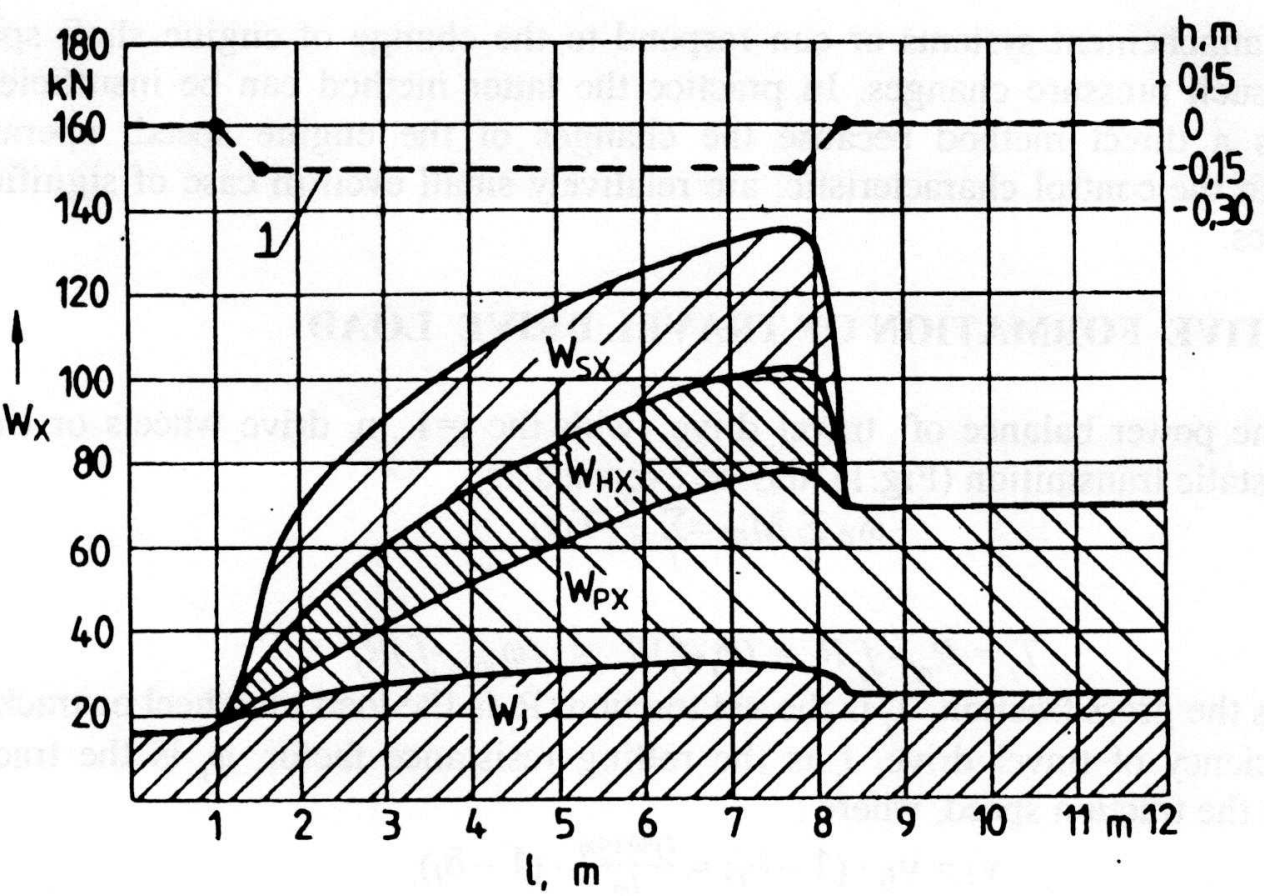

b)

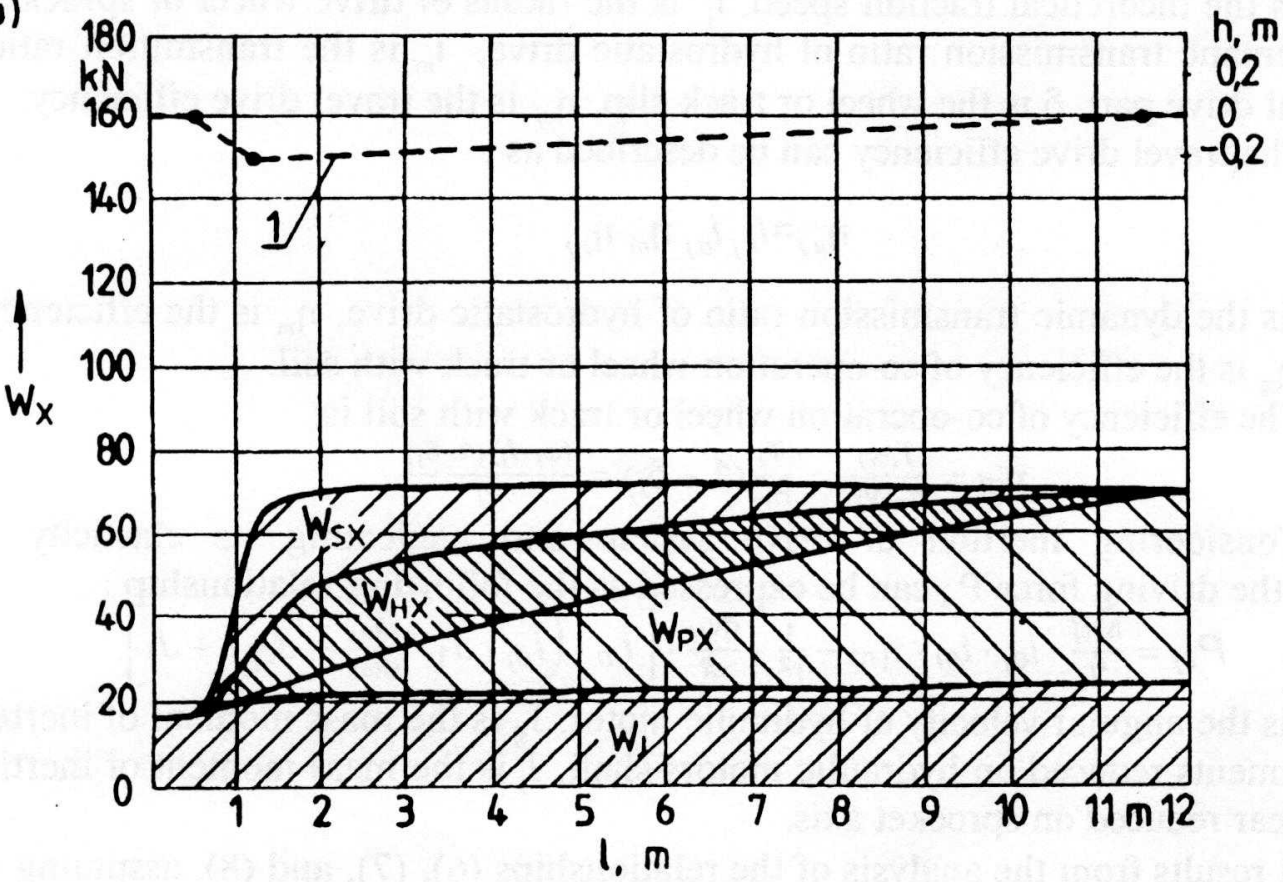

Fig.4. Horizontal components of load resistances of SG-15 bulldozer during ground mining for a) flat manner of filling , b) filling with continuous lift of blade, $\mathrm{W}_{\mathrm{ax}}$ is the cut resistance, $\mathrm{W}_{\mathrm{hx}}$ is the resistance of the ground displacement up the bulldozer blade, $\mathrm{W}_{\mathrm{px}}$ is the resistance of the pile pushing, $\mathrm{W}_{\mathrm{j}}$ is the rolling resistance, $l$ is the cut profile, $I$ is the length of machine travel during filling process

A productivity of the tractor machine depends mainly on the operating travel speed which is limited not only by the engine power but also by abilities of an operator 
3) the running gears operate in the slip condition and dependence $\varphi_{j}(1-\delta)=\max$ (Fig.3).

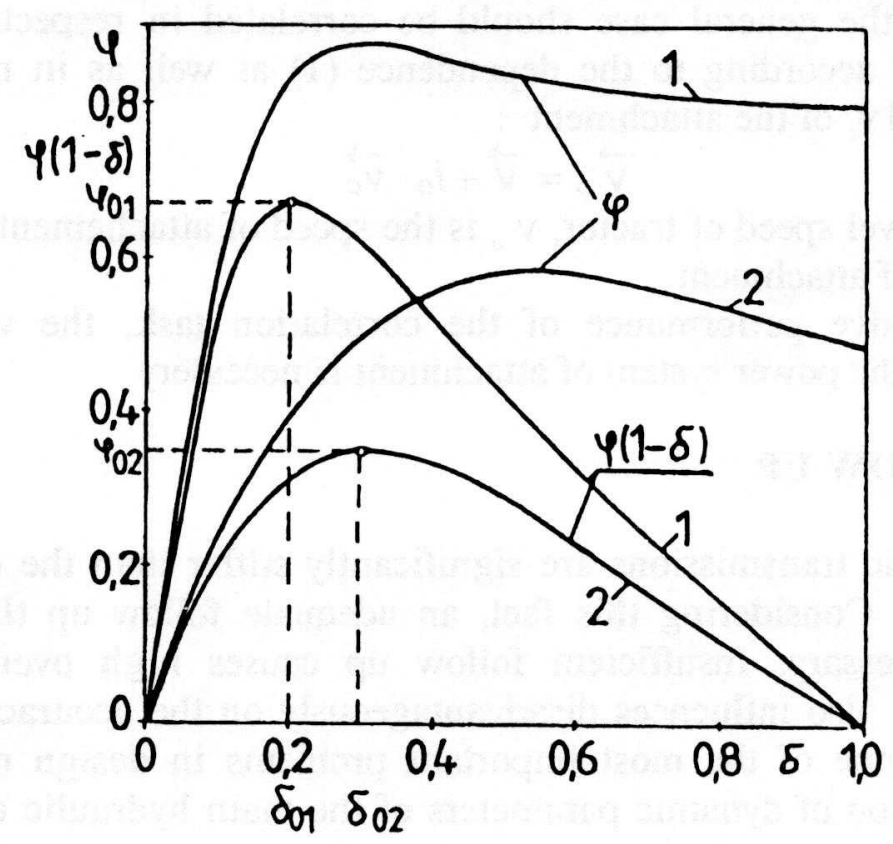

Fig.3. Tyre traction factor $\varphi$ for firm (1) and soft (2) soil vs. slip $\delta$

The above conditions can be relatively easy satisfied if there is a possibility to accomplish the machine working process for the fixed attachment loads (Fig.4). Then, the travelling speed can be calculated from the equation :

$$
\sum_{j} P_{n j}-\Sigma W_{x}-W_{j}-m \cdot \frac{\alpha}{d \cdot t}=0
$$

where $\Sigma W_{x}$ is the total horizontal working resistance component, $m$ is the mass of machine.

The rolling resistances of the machine travelling on the surface inclined at the angle $\alpha=0$, assuming no air resistances, are equal to :

$$
W_{j}=\Sigma f_{i} \cdot R_{j}=f \cdot\left(m \cdot g+W_{y}\right)
$$

where $\mathrm{W}_{\mathrm{y}}$ is the vertical conponent of operate resistance.

\section{SYNCHRONIZATION AND CONTROL CORRELATION}

The wheels or tracks driving by means of separate hydrostatic transmissions of adequately low power significantly increases the machine mobility [8]. However, it causes a necessity to control a synchronization of the settings $\varepsilon_{\mathrm{pj}}$ and $\varepsilon_{\mathrm{gj}}$ in order to obtain the same or adequately diversified travelling speeds of each track (5) which ensure the fixed travelling path. Therefore, one question appeares : should the synchronization system react only to the speed of hydraulic motors $\omega_{i j}$ or to the slip effect $\delta$ too. 
who must follow up the control of attachment, during the excavation process according to technical conditions of the performed works. The control of travel drive and piston rod of attachment in the general case should be correlated in respect of optimum loading of the engine, according to the dependence (1) as well as in respect of the required absolute speed $v_{0}$ of the attachment :

$$
\vec{v}_{o}=\vec{v}+i_{0} \cdot \overrightarrow{v_{c}}
$$

where $v$ is the real travel speed of tractor, $v_{0}$ is the speed of attachement cylinder, $i_{\circ}$ is the kinematic ratio of attachment.

For the effective performance of the correlation task, the volumetric or trottling regulation in the power system of attachment is necessery

\section{CONTROL FOLLOW UP}

The hydrostatic transmissions are significantly stiffer than the transmissions with torque converter. Considering this fact, an adequate follow up the settings of hydraulic unit is necessary. Insufficient follow up causes high overloads in the transmission (fig.5). It also influences disadvantageously on the accuracy of machine operation. Therefore, one of the most important problems in design of hydrostatic travel drive is a selection of dynamic parameters of the main hydraulic unit and their controllers.

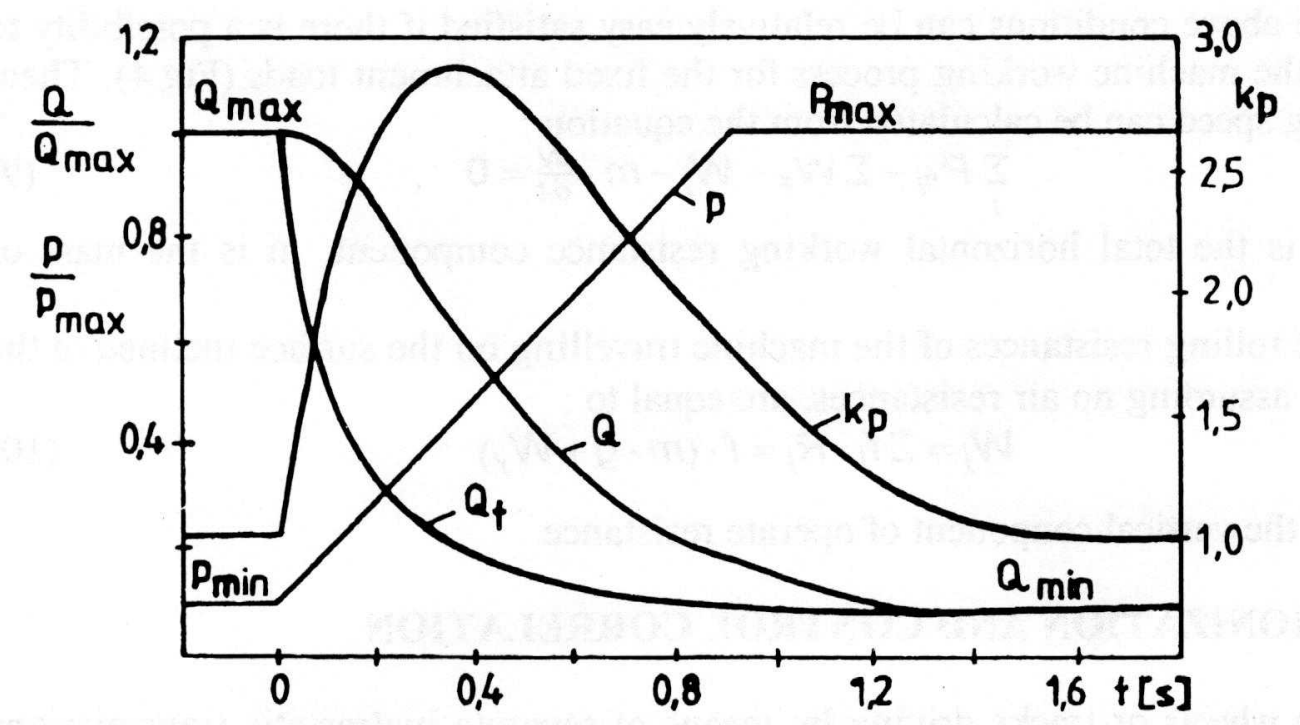

Fig.5. Theoretical $\left(Q_{t}\right)$ and real $(Q)$ delivery for linear pressure increase (p) for controller witch time constant $\tau=0.25 \mathrm{~s}, \mathrm{k}_{\mathrm{p}}$ is the overload ratio

The required control of the hydraulic transmission during the working process can be approximately estimated on the basis of the traction ratio of hydrokinetic drive (Fig.6) which automatically change under the load condition. However, the stepless transmission ratios $i_{k}$ and $i_{d}$ of hydrostatic drive are : 


$$
i_{k}=\frac{q_{\rho} \varepsilon_{p}}{q_{s} \varepsilon_{s}} \cdot \eta_{v p} \cdot \eta_{v s} \text { oraz } i_{d}=\frac{q_{s} \varepsilon_{s}}{q_{\rho} \varepsilon_{\rho}} \cdot \eta_{m h p} \cdot \eta_{m h s}
$$

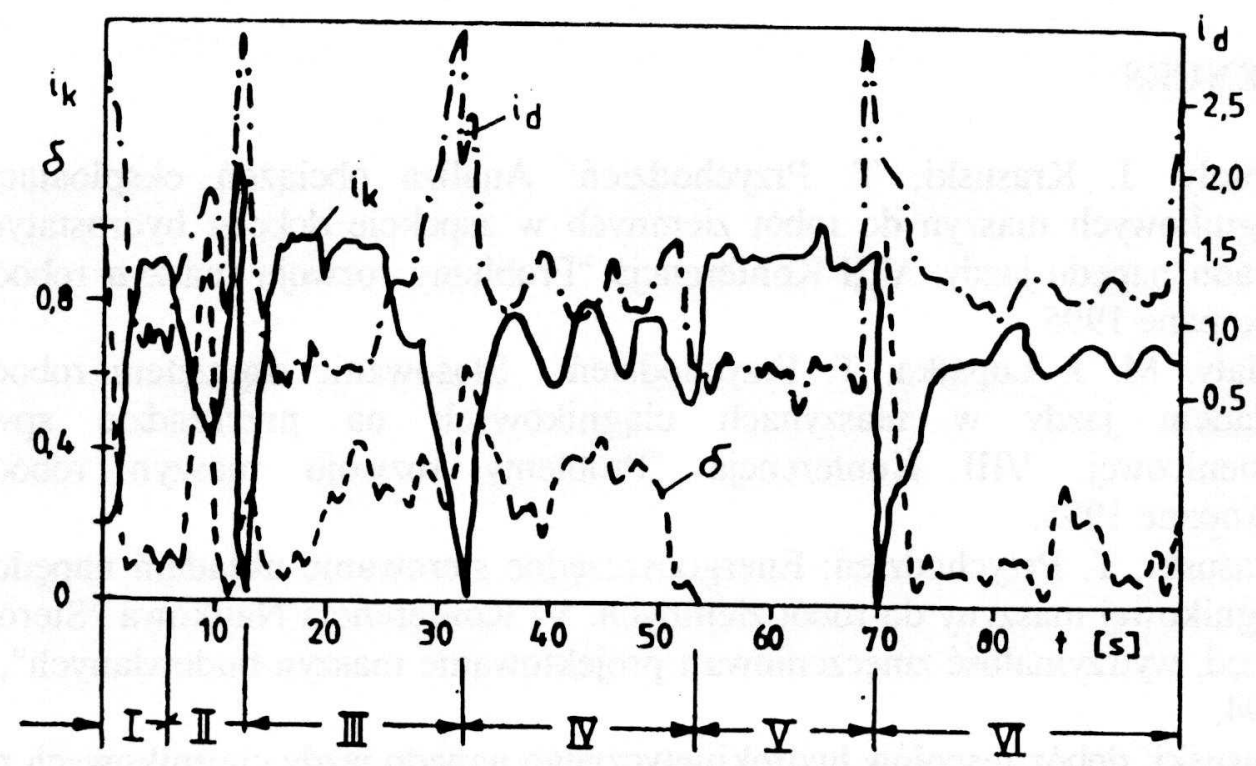

Fig. 6. Diagram of torque converter parameters $i_{k}, i_{d}$ and slip $\delta$ for work cycle of loader

where $\eta_{\mathrm{vp}}, \eta_{\mathrm{vs}}, \eta_{\mathrm{mhp}}, \eta_{\mu \eta o}$ are the volumetric and mechanic efficiencies of pump and motor, respectively. It should be noticed that the chart for hydrostatic transmission relation $i_{d}\left(i_{k}\right)$ is of hyperbolic shape while for the hydrokinetic drive the chart is linear. Therefore, the ranges of transmission ratio changes in these both cases will be different.

\section{CONCLUSION}

The effective control of the hydrostatic travel transmission of the earthmovers is complicated task of dynamic multi-criterion optimization which requires a continiuous or enough repeated sampling and processing from the point of view of searching for the optimum decisions.

An accomplishment of this task, only in respect of one criterion, is too difficult for operator and additional automation-aided system using micro-processor is necessary. However, a character of the working processes of the earth-movers is such complicated that full automation of their control is impossible in the nearest time. It is not possible to applied the mechatronic systems instead a man because of the necessity of taking decision in the case of incomplete information. Thus, the main research task is an optimum selection of the control activities for operator and automatic systems in dependence on technology and operating conditions of earth-movers. 
Serching for the best solutions of this task requires to work out the new method of analysis and synthesis of hydrostatic drive control systems for tractor earth-movers.

\section{REFERENCES}

[1] J. Biały, J. Krasuski, T. Przychodzień: Analiza obciążeń eksploatacyjnych ciagnikowych maszyn do robót ziemnych $w$ aspekcie doboru hydrostatycznego układu napedu jazdy. VIII Konferencja "Problemy rozwoju maszyn roboczych", Zakopane 1995.

[2] J. Biały, M. J. Lopatka, T. Przychodzień : Stosowanie osprzętem roboczym i ukladem jazdy $w$ maszynach ciagnikowych na przykladzie spycharki gasienicowej. VIII Konferencja "Problemy rozwoju maszyn roboczych", Zakopane 1995.

[3] J. Krasuski, T. Przychodzień: Energooszczędne sterowanie układem napędu jazdy ciagnikowej maszyny do robót ziemnyck. VI Konferencja Naukowa "Sterowanie, napęd, wytrzymałość zmęczeniowa i projektowanie maszyn budowlanych", Rynia 1994.

[4] J. Krasuski: dobór zespolów hydrokinetycznego napędu jazdy ciagnikowych maszyn roboczych. Rozprawa habilitacyjna WAT, Warszawa 1992.

[5] J. Krasuski: Dynamiczna charakterystyka trakcyjna pojazdu z hydrokinetycznym ukladem. Biuletyn WAT, nr 12/1994.

[6] J. Krasuski, F. Kuczmarski: Kryteria efektywnego sterowania procesem roboczym maszyn do robót ziemnych. Biuletyn WAT, $\mathrm{nr}$ 12/1992.

[7] M. J. Łopatka: Nadażnosć hydraulicznych układów napędowych maszyn roboczych. Rozprawa doktorska WAT, Warszawa 1993.

[8] L. Orlowski: Nowoczesne układy napędowe i bieżne wozów bojowych. Wojskowy Przegląd Techniczny i Logistyczny 8/92. 